\title{
Absorption of Slow-release Iron and Effects of Ascorbic Acid in Normal Subjects and after Partial Gastrectomy
}

\author{
I. McLEAN BAIRD, R. L. WALTERS, D. R. SUTTON
}

British Medical fournal, 1974, 4, 505-508

\section{Summary}

Radiolabelled tablets of slow-release iron and ferrous sulphate containing $50 \mathrm{mg}$ of elemental iron were given to 28 patients, and iron absorption was studied using a whole body counter.

There was no significant difference between the absorption of ferrous sulphate and that of slow-release iron in normal subjects, anaemic patients, anaemic and non-anaemic postgastrectomy patients, or those with coeliac disease. Ascorbic acid potentiated iron absorption, especially in anaemic postgastrectomy patients.

The indications and hazards of slow release iron preparations are discussed.

\section{Introduction}

Slow-release iron preparations are widely used in the treatment of iron-deficiency anaemia because of their convenient administration once a day and fewer side effects compared with conventional ferrous sulphate (Webster, 1962). Criticism has been made of slow-release iron because of expense and impaired absorption (Dagg, 1974). Most studies of the absorption of such preparations have been in subjects without upper gastrointestinal disease (Bothwell et al., 1958; CroslandTaylor et al., 1965; Callender, 1969). Turnbull (1971) recommended that iron-deficiency anaemia in subjects with a partial gastrectomy ought not to be treated with slow-release iron since rapid transit of the tablets might prejudice absorption. Little experimental evidence of iron retention in postgastrectomy patients has been reported, however, except by Parker et al. (1972), who did not show any difference between delayed-release iron and conventional ferrous sulphate.

The present study contrasts iron absorption with therapeutic preparations of ferrous sulphate, slow-release iron, and slow-release iron with ascorbic acid in subjects who had had a partial gastrectomy, some of whom had iron-deficiency anaemia, and normal subjects, both anaemic and nonanaemic. We studied also the absorption of the same iron preparations in patients with adult coeliac disease.

\section{Patients and Methods}

Six normal volunteers (group 1) and five patients with irondeficiency anaemia (group 2) with no clinical evidence of upper gastrointestinal disease acted as controls. Eight nonanaemic patients (group 3) and five patients with irondeficiency anaemia (group 4) were investigated. All these patients had had a Polya's partial gastrectomy more than one year previously.

In the control and partial gastrectomy anaemic subjects anaemia was arbitrarily defined as a haemoglobin level below

West Middlesex Hospital, Isleworth, Middlesex TW7 6AF

I. MCLEAN BAIRD, M.D., F.R.C.P., Physician

R. L. WALTERS, M.B., M.R.C.P., Research Registrar

D. R. SUTTON, M.D., M.R.C.P., Senior Registrar

$13 \mathrm{~g} / 100 \mathrm{ml}$ for men and below $11 \mathrm{~g} / 100 \mathrm{ml}$ for women. Anaemic patients had a hypochromic appearance on blood film examination and responded to oral iron with a rise in haemoglobin to normal. Serum iron and total iron binding capacity estimations were made in most control and partial gastrectomy subjects.

Four patients with adult coeliac disease (group 5), all of whom were on a normal diet, were also investigated. Three had been previously diagnosed and were non-anaemic. Jejunal biopsies showed flat mucosa, some with mosaic mucosa, on dissecting microscope examination (Holmes et al., 1961). Histological examination showed increased mucosal thickness with reduced epithelial surface cell height and increased inflammatory cells, fulfilling the criteria of Stewart et al. (1967).

No patient had received any iron therapy for one month before investigation.

\section{IRON PREPARATIONS}

The three iron preparations used in a randomized order were ferrous sulphate, a slow-release iron, and slow-release iron given with a separate tablet of $500 \mathrm{mg}$ of ascorbic acid. Each iron tablet contained an equivalent amount of $50 \mathrm{mg}$ of elemental iron labelled with $33 \mu \mathrm{Ci}$ of ${ }^{59} \mathrm{Fe}$ and was taken with a drink of water.

The slow-release tablet consisted of a wax matrix, upon which was formulated dried ferrous sulphate. The tablet was designed to release its iron over a period of 90-120 minutes. The slow-release iron tablet was of identical formulation and bioavailability as that commercially available (Slow-Fe, Ciba Laboratories). Ferrous sulphate tablets were made according to the standard B.P.C. formulation.

\section{TECHNIQUES}

Haematological estimations followed standard laboratory techniques (Dacie and Lewis, 1963). Serum iron and total iron binding capacity were estimated according to the method of Young and Hicks (1965). The whole body counter, similar to that used by Warner and Oliver (1965), was used to measure absorption. Each iron preparation was administered on two successive days using the multiple-dose technique described by Callender and Warner (1968) to reduce biological variations of iron absorption. Patients were fasted for at least eight hours before taking a tablet and recounted 90 minutes after taking it. The absorption of the double dose was measured by estimating the retained radioactivity at 14 days.

\section{Results}

There were no significant differences between the absorption of the slow-release iron and that of ferrous sulphate in any of the clinical groups examined. For example, the absorption of ferrous sulphate in five anaemic subjects after pantial gastrectomy was $16.5 \pm 0.9 \%$ and that of the slow-release iron was $14.8 \pm 2.2 \%$ (table I). Even in the patients with adult coeliac disease there were no significant differences between absorption of ferrous sulphate (7.3\%) and absorption of slow-release iron $(7 \cdot 1 \%)$. 
TABLE I-Absorption Studies of Ferrous Sulphate, Slow-release Iron, and Slow-release Iron with Ascorbic Acid in Five Groups of Patients

\begin{tabular}{|c|c|c|c|c|c|c|c|c|c|c|}
\hline \multirow[b]{2}{*}{$\begin{array}{l}\text { Case } \\
\text { No. }\end{array}$} & \multirow{2}{*}{\multicolumn{2}{|c|}{ Age and Sex }} & \multirow[b]{2}{*}{ Diagnosis } & \multirow[b]{2}{*}{$\begin{array}{c}\text { Haemoglobin } \\
(\mathrm{g} / 100 \mathrm{ml})\end{array}$} & \multirow[b]{2}{*}{ Blood Film } & \multirow[b]{2}{*}{$\begin{array}{l}\text { Serum Iron } \\
(\mu \mathrm{g} / \mathbf{1 0 0} \mathrm{ml})\end{array}$} & \multirow[b]{2}{*}{$\begin{array}{c}\text { Total Iron } \\
\text { Binding Capacity } \\
(\mu \mathrm{g} / 100 \mathrm{ml})\end{array}$} & \multicolumn{3}{|c|}{ Absorptions (\%) } \\
\hline & & & & & & & & $\begin{array}{l}\text { Ferrous } \\
\text { Sulphate }\end{array}$ & $\begin{array}{c}\text { Slow-release } \\
\text { Iron }\end{array}$ & \begin{tabular}{|c} 
Slow-release \\
Iron + Ascorbic \\
Acid \\
\end{tabular} \\
\hline \multirow[t]{2}{*}{$\begin{array}{l}1 \\
2 \\
3 \\
4 \\
5 \\
6\end{array}$} & \multirow{2}{*}{\multicolumn{2}{|c|}{$\begin{array}{l}\text { M. } \\
\text { M. } \\
\text { F. } \\
\text { F. } \\
\text { F. }\end{array}$}} & \multirow[t]{2}{*}{$\begin{array}{c}\text { Normal } \\
\text { ” } \\
\text { ” }\end{array}$} & \multirow[t]{2}{*}{$\begin{array}{l}16 \cdot 4 \\
14 \cdot 2 \\
14 \cdot 1 \\
12 \cdot 7 \\
13 \cdot 4 \\
14 \cdot 2\end{array}$} & \multirow[t]{2}{*}{$\begin{array}{l}\text { Group 1. Norm } \\
\text { Normal } \\
\text { Normal } \\
\text { Normal } \\
-\end{array}$} & $\begin{array}{l}\text { l Control Subj } \\
82 \\
165 \\
65 \\
105 \\
112 \\
80\end{array}$ & $\begin{array}{l}387 \\
315 \\
345 \\
375 \\
360\end{array}$ & $\begin{array}{r}2 \cdot 1 \\
0 \\
6 \cdot 1 \\
4 \cdot 3 \\
5 \cdot 1 \\
15 \cdot 4\end{array}$ & $\begin{array}{r}7 \cdot 2 \\
6 \cdot 6 \\
6 \cdot 7 \\
4 \cdot 8 \\
5 \cdot 2 \\
11 \cdot 8\end{array}$ & $\begin{array}{l}10 \cdot 2 \\
6 \cdot 6 \\
13.0 \\
0.7 \\
12 \cdot 4 \\
16 \cdot 3\end{array}$ \\
\hline & & & & & & \multicolumn{2}{|c|}{ Mean \pm S.E. of Mean } & $5 \cdot 5 \pm 2 \cdot 2$ & $7 \cdot 1 \pm 1 \cdot 0$ & $9 \cdot 9 \pm 2 \cdot 2$ \\
\hline \multicolumn{11}{|c|}{ Group 2. Control Subjects with Hypochromic Anaemia } \\
\hline 7 & 46 & M. & Bleeding & $8 \cdot 0$ & Hypochromia & $1-$ & $1-$ & $19 \cdot 4$ & $23 \cdot 1$ & $20 \cdot 7$ \\
\hline 8 & 28 & F. & Iron deficiency, & $9 \cdot 4$ & ” & 30 & 140 & $17 \cdot 8$ & 10.9 & $19 \cdot 7$ \\
\hline 9 & 49 & F. & Iron deficiency, & $8 \cdot 4$ & ” & 20 & 420 & $12 \cdot 1$ & 17.5 & $20 \cdot 1$ \\
\hline 10 & 62 & F. & Iron deficiency, & $10 \cdot 6$ & " & - & - & 21.9 & $28 \cdot 0$ & $29 \cdot 2$ \\
\hline \multirow[t]{2}{*}{11} & \multirow[t]{2}{*}{69} & \multirow[t]{2}{*}{ F. } & Carcinomatosis* & \multirow[t]{2}{*}{$10 \cdot 2$} & \multirow[t]{2}{*}{ ” } & 20 & 450 & 23.5 & $26 \cdot 2$ & 22.7 \\
\hline & & & & & & \multicolumn{2}{|c|}{ Mean \pm S.E. of Mean } & $18 \cdot 9 \pm 2 \cdot 0$ & $21 \cdot 1 \pm 3 \cdot 1$ & $22.5 \pm 1.7$ \\
\hline \multirow{3}{*}{$\begin{array}{l}12 \\
13 \\
14 \\
15 \\
16 \\
17 \\
18 \\
19\end{array}$} & \multirow{3}{*}{\multicolumn{2}{|c|}{$\begin{array}{l}65 \\
67 \\
48 \\
48 \\
57 \\
57 \\
60 \\
64\end{array}$}} & & \multirow{3}{*}{\multicolumn{2}{|c|}{\begin{tabular}{l|l} 
Group 3. Non-anaemic Subjects w \\
\begin{tabular}{c|l}
13.9 & Normal \\
13.1 & Macrocytosis \\
11.6 & Normal \\
12.6 & Normal \\
12.0 & Normal \\
11.4 & Anisocytosis \\
13.1 & Normal \\
13.0 & "
\end{tabular}
\end{tabular}}} & had had Poly & Partial Gastrectomy & & & \\
\hline & & & & & & $\begin{array}{r}150 \\
75 \\
115 \\
115 \\
145 \\
126 \\
120 \\
120\end{array}$ & $\begin{array}{l}300 \\
195 \\
450 \\
435 \\
510 \\
498 \\
450 \\
-\end{array}$ & $\begin{array}{r}6.0 \\
19 \cdot 7 \\
14 \cdot 1 \\
15 \cdot 2 \\
13.8 \\
8.7 \\
8 \cdot 7 \\
17 \cdot 0\end{array}$ & $\begin{array}{r}6 \cdot 0 \\
13.7 \\
17.5 \\
12.7 \\
10 \cdot 1 \\
8 \cdot 2 \\
4.9 \\
16.4\end{array}$ & $\begin{array}{l}15 \cdot 1 \\
19 \cdot 3 \\
13.5 \\
17 \cdot 8 \\
11 \cdot 2 \\
8 \cdot 0 \\
11 \cdot 8 \\
19 \cdot 7\end{array}$ \\
\hline & & & & & & & an \pm S.E. of Mean & $12 \cdot 9 \pm 1 \cdot 7$ & $11 \cdot 2 \pm 1 \cdot 7$ & $14 \cdot 6 \pm 1 \cdot 5$ \\
\hline \multirow{3}{*}{$\begin{array}{l}20 \\
21 \\
22 \\
23 \\
24\end{array}$} & \multirow{3}{*}{\multicolumn{2}{|c|}{$\begin{array}{l}52 \\
54 \\
67 \\
55 \\
65\end{array}$}} & & \multirow{3}{*}{\multicolumn{2}{|c|}{\begin{tabular}{l|c} 
Group 4. Anaemic Subjects who \\
12.9 & Hypochromia \\
$10 \cdot 0$ & $\#$ \\
10.9 & $\#$ \\
10.1 & $\#$ \\
$9 \cdot 0$ & $\#$
\end{tabular}}} & lad had Polya & rtial Gastrectomy & & & \\
\hline & & & & & & \begin{tabular}{|l}
25 \\
50 \\
58 \\
25
\end{tabular} & $\begin{array}{l}495 \\
464 \\
540 \\
510\end{array}$ & $\begin{array}{l}15.9 \\
14 \cdot 4 \\
19.8 \\
15.3 \\
17.0 \\
\end{array}$ & $\begin{array}{l}18 \cdot 0 \\
19 \cdot 1 \\
15 \cdot 0 \\
6 \cdot 4 \\
15 \cdot 7 \\
\end{array}$ & $\begin{array}{l}19 \cdot 4 \\
24.8 \\
31.4 \\
20.1 \\
21 \cdot 4\end{array}$ \\
\hline & & & & & & \multicolumn{2}{|c|}{ Mean \pm S.E. of Mean } & $16.5 \pm 0.9$ & $14 \cdot 8 \pm 2 \cdot 2$ & $23 \cdot 4 \pm 2 \cdot 2$ \\
\hline \multirow{3}{*}{$\begin{array}{l}25 \\
26 \\
27 \\
28\end{array}$} & \multirow{3}{*}{\multicolumn{2}{|c|}{$\begin{array}{ll}56 & \text { M. } \\
27 & \text { F. } \\
41 & \text { F. } \\
56 & \text { F. }\end{array}$}} & & \multirow{3}{*}{$\begin{array}{r}14 \cdot 6 \\
12 \cdot 7 \\
7 \cdot 6 \\
12 \cdot 4\end{array}$} & p. Subjects wit & Adult Coelia & isease & & & \\
\hline & & & & & \multirow[t]{2}{*}{$\begin{array}{l}\text { Normal } \\
\text { Hypochromia } \\
\text { Normal }\end{array}$} & \multirow[t]{2}{*}{$\begin{array}{r}\frac{}{32} \\
100\end{array}$} & $\begin{array}{r}\overline{7} \\
\mathbf{4 9 2} \\
390\end{array}$ & $\begin{array}{r}7.7 \\
1.7 \\
9 \cdot 2 \\
10.5\end{array}$ & $\begin{array}{l}6.4 \\
6.5 \\
9.5 \\
5.8\end{array}$ & $\begin{array}{r}5.1 \\
5.8 \\
17.4 \\
12.2\end{array}$ \\
\hline & & & & & & & Mean & $7 \cdot 3$ & $7 \cdot 1$ & $10 \cdot 1$ \\
\hline
\end{tabular}

*Diagnosed subsequently.

All five groups showed the best absomption to be with the preparation supplemented with ascorbic acid. In the partial gastrectomy patients with anaemia this effect reached significance, the combined preparation being better absorbed than the slow-release iron alone $(P<0.05)$ or ferrous sulphate $(P<0.02)$ (table II). The results with the other groups were not significant.

The well-accepted potentiation of iron absorption in iron deficiency was readily apparent in the control subjects with all three iron preparations-for example, the absorption of ferrous sulphate rose from $5.5 \% \pm 2.2 \%$ in non-anaemic subjects to $18.9 \% \pm 4.4 \%$ in the anaemic ones. The rise was significant for each preparation $(P<0.01)$.

Similar potentiation occurred in the partial gastrectomy subjects, but it was not significant for ferrous sulphate or slow-release iron (table I).

The iron tablet supplemented with ascorbic acid did show the potentiated absomption due to anaemia, values increasing from $14.5 \pm 1.5 \%$ in the non-anaemic postgastrectomy patients to $23.4 \pm 2.2 \%$ in the equivalent anaemic group $(\mathrm{P}<0.01)$.

The total iron binding capacity and absorption of all three

TABLE II-Comparison of Absorption of Iron Preparations in Controls and Partial Gastrectomy Patients using Paired $t$ Tests

\begin{tabular}{|c|c|c|c|c|c|c|}
\hline \multirow{2}{*}{ Group } & \multicolumn{2}{|c|}{ Ferrous Sulphate $v$. Slow-release Iron } & \multicolumn{2}{|c|}{$\begin{array}{l}\text { Ferrous Sulphate } v \cdot \\
\text { Slow-release Iron + Ascorbic Acid }\end{array}$} & \multicolumn{2}{|c|}{$\begin{array}{l}\text { Slow-release Iron v. } \\
\text { Slow-release Iron + Ascorbic Acid }\end{array}$} \\
\hline & $t$ & $\mathbf{P}$ & $t$ & $\mathbf{P}$ & $t$ & $\mathbf{P}$ \\
\hline $\begin{array}{l}1 \\
2 \\
3 \\
4\end{array}$ & $\begin{array}{r}-1.024 \\
-0.935 \\
1.667 \\
0.678\end{array}$ & $\begin{array}{l}<0.4 \\
<0.5 \\
<0.2 \\
<0.6\end{array}$ & $\begin{array}{l}-2 \cdot 286 \\
-2.034 \\
-1 \cdot 284 \\
-4.127\end{array}$ & $\begin{array}{l}<0.1 \\
<0.2 \\
<0.3 \\
<0.02\end{array}$ & $\begin{array}{l}-1.626 \\
-0.578 \\
-1.589 \\
-3.077\end{array}$ & $\begin{array}{l}<0.2 \\
<0.6 \\
<0.2 \\
<0.05\end{array}$ \\
\hline
\end{tabular}

TABLE III-Comparison of Absorption of each Iron Preparation by different Groups using Unpaired $t$ Tests

\begin{tabular}{|c|c|c|c|c|c|c|}
\hline \multirow{2}{*}{$\begin{array}{c}\text { Groups } \\
\text { Compared }\end{array}$} & \multicolumn{2}{|c|}{ Ferrous Sulphate } & \multicolumn{2}{|c|}{ Slow-release Iron } & \multicolumn{2}{|c|}{ Slow-release Iron + Ascorbic Acid } \\
\hline & $t$ & $\mathbf{P}$ & $\boldsymbol{t}$ & $\mathbf{P}$ & $t$ & $\mathbf{P}$ \\
\hline $\begin{array}{ll}1 & v .3 \\
2 & v .4 \\
1 & v .2 \\
3 & v .4\end{array}$ & $\begin{array}{r}-2.762 \\
1.128 \\
-4.493 \\
-1.593\end{array}$ & $\begin{array}{l}<0.02 \\
<0.3 \\
<0.005 \\
<0.2\end{array}$ & $\begin{array}{r}-1.959 \\
1.639 \\
-4.643 \\
-1.338\end{array}$ & $\begin{array}{l}<0.1 \\
<0.2 \\
<0.005 \\
<0.3\end{array}$ & $\begin{array}{l}-1.811 \\
-0.334 \\
-4.270 \\
-3.482\end{array}$ & $\begin{array}{l}<0.1 \\
<0.8 \\
<0.005 \\
<0.01\end{array}$ \\
\hline
\end{tabular}


iron preparations were higher in the non-anaemic partial gastrectomy subjects than in normal controls. The difference in absorption achieved significance for ferrous sulphate $(\mathrm{P}<0.02$; table III). These differences from normal subjects are suggestive of early iron deficiency in the partial gastrectomy group despite the presence of normal serum iron values.

Iron absorption in the non-anaemic adult coeliac patients was not very different from that in the normal controls, but the anaemic patient (case 27) did not show a uniformly enhanced absorption due to iron deficiency. In this patient the absorption of ferrous sulphate was $9.2 \%$ compared with $9.5 \%$ with slow-release tablets, and potentiation occurred up to $17 \cdot 4 \%$ absorption with slow-release iron and ascorbic acid.

\section{Discussion}

This study showed no differences in the absorption of ferrous sulphate and Slow-Fe in patients who had undergone partial gastrectomy, confirming the work of Parker et al. (1972). This conclusion does not necessarily apply to slowrelease preparations other than Slow-Fe which have different formulations.

Ferrous sulphate tablets are cheap and effective in the treatment of most patients with iron deficiency. Studies using isotopic or haemoglobin-regeneration techniques in subjects with intact stomachs have usually shown ferrous sulphate to be equally or more effectively absorbed than sustainedrelease preparations (Bothwell et al., 1958; Layrisse, 1963; Crosland-Taylor et al., 1965). In our control groups we have shown a similar finding. Crosby (1966) has criticized slowrelease preparations as illogical because they release iron when past the duodenum, which is the site of maximum iron absorption. Heinrich et al. (1972) extended the argument, saying that the localization of side effects is transferred from the stomach to the intestine. In favour of sustained-release preparations Norrby and Solvell (1971) found the slowrelease formulation was $29 \%$ better absorbed than ferrous sulphate. This same preparation, in a large and wellconducted trial in 1,376 patients, caused a lower incidence of nausea and epigastric pain than ferrous sulphate and a comparable incidence of diarrhoea and constipation (Rybo and Solvell, 1971). Our findings suggest that slow-release preparations can be used with the confidence that they will be absorbed as well as ferrous sulphate even in patients with postgastrectomy anaemia. This type of absorption study cannot evaluate side effects, which requires larger groups and a longer period of therapy.

Ascorbic acid has been shown to increase the absorption of iron in subjects with intact stomachs by some authors (Brise and Hallberg, 1962; McCurdy and Dern, 1968) but not by others (Callender and Warner, 1969; Heinrich et al., 1972). Orange juice in subjects with intact stomachs (Callender and Warner, 1968) and oranges in subjects who have undergone partial gastrectomy (Turnbull, 1965) have enhanced absorption of iron, possibly due to ascorbic acid. In patients who had had partial gastrectomy Williams (1959) showed greatly increased absorption of a low dose of iron with ascorbic acid. An iron absorption promoting effect by ascorbic acid may be mediated by maintaining the reduced ferrous ion or by forming the low molecular weight ligand, ferrous ascorbate (Jacobs, 1971).

We found that the preparation supplemented with ascorbic acid had the highest level of absorption in each group, and this was significant in the partial gastrectomy anaemic group compared to ferrous sulphate $(P<0.02)$ and compared to the slow-release iron $(P<0.05)$. These anaemic patients also absorbed significantly more iron from the supplemented preparation than did the non-anaemic partial gastrectomy group, but such a significant increase was not found in the case of the other iron preparations. These findings suggest a particular benefit of ascorbic acid in anaemic partial gastrec- tomy patients, which could be explained by a high prevalence of atrophic gastritis and associated achlorhydria.

We have found evidence in the raised total iron binding capacity and iron absorption results of the partial gastrectomy non-anaemic subjects, in relation to the normal controls, to suggest that the former have reduced iron stores. Stammers and Williams (1963) have previously reported an increased iron-binding capacity, in the presence of a normal serum iron level and blood film, after partial gastrectomy. A similar group of postgastrectomy subjects investigated by Turnbull (1965) absorbed more radioiron than healthy controls, the suggested reason being suboptimal iron stores. Two studies of inorganic iron absomption carried out shortly after partial gastrectomy failed to show any change compared with preoperative values (Smith and Mallett, 1957; Baird et al., 1957).

Our absorption studies were carried out in the fasting state, where conditions were optimal for maximum absorption of iron. Brise (1962) showed that iron absorption was halved when taken after meals. In MIMS (1974), however, only five out of 46 oral iron preparations were recommended to be taken before meals or between meals, and it is uncertain how many patients take iron in the fasting state.

A low absorption of physiological doses of iron has been reported in patients with untreated coeliac disease by Badenoch and Callender (1960). Sutton (1972) showed little enhancement of absomption in anaemic coeliac patients when compared to non-anaemic coeliac controls. Our non-anaemic coeliac subjects absorbed a therapeutic dose of iron comparably to the controls, except for one patient with an absorption of $1.7 \%$. The absence of an appropriate level of enhancement of absorption in the presence of anaemia in case 27 doses, however, suggests malabsorption of iron.

Patients known to have strictures of the alimentary tract such as occur in Crohn's disease or neoplasia (Spigelman and $\mathrm{McNabb}, 1971)$ probably should not receive slow-release preparations. Obstruction due to retention of unaltered matrix or mucosal damage from a high local concentration of iron are both potential hazards. Because of these dangers and the expense we do not advise slow-release preparations as a "first choice" oral iron therapy but prefer to use them for patients with intolerance to ferrous sulphate, where they will be equally well absorbed and as effective in haemoglobin regeneration.

Grateful acknowledgement to Dr. D. M. Burley for supplying the Slow-Fe tablets and to the Clinical Research Committee of the North-west Metropolitan Regional Hospital Board for a research grant.

\section{References}

Badenoch, J., and Callender, S. T. (1960). Lancet, 1, 192.

Baird, I. M., Podmore, D. A., and Wilson, G. M. (1957). Clinical Science, 16,453 .

Bothwell, T. H., Prizio-Biroli, G., and Finch, C. H. (1958). Journal of Laboratory and Clinical Medicine, 51, 24.

Brise, H., and Hallberg, L. (1962). Acta Medica Scandinavica, 171, Suppl. No. 376, p. 23.

Callender, S. T. (1969). British Medical fournal, 4, 531.

Callender, S. T., and Warner, G. T. (1968). American fournal of Clinical Nutrition, 21,1170 .

Callender, S. T., and Warner, G. T. (1969). British Medical fournal, 4, 532. Crosby, W. H. (1966). Disease a Month, 1-72.

Crosland-Taylor, P., Keeling, D. H., and Cromie, B. W. (1965). Current Therapeutic Research, 7, 244.

Dacie, J. V., and Lewis, S. M. (1963). Practical Haematology, Churchill, London.

Dagg, J. H., (1974). British Medical fournal, 2, 494.

Heinrich, H. C., et al. (1972). Arzneimittel-Forschung, 22, 1091. Holmes, R., Hourihane, D. O., and Booth, C. C. (1961). Lancet, 1, 81. A. M. Dawson, fournal of Clinical Pathology, 24, Suppl. 55.

Layrisse, M. (1963). Current Therapeutic Research, 5, 232

McCurdy, P. R., and Dern, R. J. (1968). American fournal of Clinical Nutrition, 2i, 284.

MIMS (Monthly Index of Medical Specialties) (1974). 16, no. 2, 133.

Norrby, A., and Sölvell, L. (1971). Scandinavian fournal of Haematology, $8,231$.

Parker, A. C., Simpson, J. D., and Richmond, J. (1972). Scottish Medical fournal, 17, 314 . 
Rybo, G., and Solvell, L. (1971). Scandinavian fournal of Haematology, $8,257$.

Smith, M. D., and Mallett, B. (1957). Clinical Science, 16, 23

Spigelman, M., and McNabb, R. W. (1971). British Medical fournal, 4, 534.

Stammers, F. A. R., and Williams, J. A. (1963). Partial Gastrectomy; Complcat J. S and Metabolic Comphict
Sutton, D. R. (1972). M.D. thesis, University of London.

Turnbull, A. L. (1965). Clinical Science, 28, 499.

Turnbull, A. L. (1971). British fournal of Hospital Medicine, 6, 573

Warner, G. T., and Oliver, R. (1966). Physics in Medicine and Biology, $11,83$.

Webster, J. J. (1962). Current Therapeutic Research, 4, 130.

Williams, J. (1959). Clinical Science, 18, 521.

Young, D. S., and Hicks, J. M. (1965). Fournal of Clinical Pathology, 18, 28.

\section{MEDICAL MEMORANDA}

\section{Imipramine Poisoning: Survival of a Child after Prolonged Cardiac Massage}

\section{P. SOUTHALL, S. M. KILPATRICK}

British Medical fournal, 1974, 4, 508

Poisoning with tricyclic antidepressants is common and the clinical features are well known (British Medical fournal, 1974; Goel and Shanks, 1974). The present case illustrates that children who develop a critically low cardiac output from tricyclic poisoning or any other potentially reversible cause should have resuscitation procedures continued for long periods before hope is abandoned.

\section{Case Report}

A girl aged 3 years 8 months and weighing $13.6 \mathrm{~kg}$ was admitted to the casualty department about one hour after ingesting $1825-\mathrm{mg}$ imipramine tablets. She was unconscious and convulsing. A monitoring oscilloscope showed a ventricular tachycardia of $120 / \mathrm{min}$. She was given two 50-joule D.C. shocks, which caused transient return to sinus rhythm followed by reversion to ventricular tachycardia. As no peripheral pulse could be felt external cardiac massage was begun and she was intubated and ventilated by hand with $100 \%$ oxygen. Internal jugular vein cut-down was performed. Central venous pressure was $2 \mathrm{~cm}$ above the sternal angle.

Diazepam, phenobarbitone, and phenytoin were given to control the convulsions, with good effect, and $20 \mathrm{mEq}$ sodium bicarbonate and $10 \mathrm{mg}$ lignocaine were injected intravenously. She remained in ventricular tachycardia and an infusion of lignocaine $0.5 \mathrm{mg} / \mathrm{min}$. and glucagon $1 \mathrm{mg} / \mathrm{hr}$ was started.

Whenever massage was stopped no peripheral pulse could be felt, and the E.C.G. monitor continued to show ventricular tachycardia. While she was receiving external cardiac massage a stomach tube was passed and a washout performed. Moderate quantities of tablet fragments were recovered. A frusemide and mannitol diuresis was started at this stage.

A fine Teflon-coated, stainless-steel pacemaker wire was then inserted via the internal jugular vein cut-down in an attempt to overdrive and thus suppress the ventricular tachycardia. As the wire entered the right atrium there was a spontaneous return to sinus rhythm and a pulse could be felt peripherally. Cardiac massage was discontinued, having been performed continuously for two and a half hours. Manual ventilation was stopped and the patient was connected to a Bennett ventilator. Five hours later her conscious level had improved to the extent that she was actively "fighting" the ventilator.

Royal Sussex County Hospital, Brighton BN2 5BE

D. P. SOUTHALL, M.B., M.R.C.P., Registrar in Medicine

S. M. KILPATRICK, M.B., B.CHIR., Registrar in Anaesthetics
Ventilation was discontinued. She was extubated and given humidified oxygen by mask.

Though initially her condition was satisfactory she developed stridor with intercostal recession. This was suggestive of laryngeal oedema, probably due to the movement of the endotracheal tube during the period of cardiac massage. Later that evening she reverted to ventricular tachycardia, possibly due to the combined effects of hypoxia and an irritable myocardium, and required further cardiac massage and D.C. cardioversion before returning to sinus rhythm. She was reintubated and ventilated overnight under the control of tubocurarine and diazepam. She was also given dexamethasone, to alleviate laryngeal oedema, and ampicillin and cloxacillin.

Next day she was allowed to breathe spontaneously; she was extubated and put in a Croupette. She made an uneventful recovery and was discharged home lively and completely well four days after admission. Though she had no obvious mental deficit at the time of discharge follow-up will be necessary to confirm that she suffered no permanent cerebral damage.

\section{Comment}

This case is particularly important because it emphasizes the value of prolonged external cardiac massage in children who develop a critically low cardiac output from tricyclic poisoning or any other potentially reversible cause. We found that several attendants performing cardiac massage for about five minutes each were able to maintain an effective output for two and a half hours. Because of the immaturity of the child's skeleton this could be achieved without rib fracture or other serious complication apart from laryngeal oedema caused by movement of the endotracheal tube.

The dual effect of imipramine on the myocardium is demonstrated. This drug not only causes arrhythmias but also has a direct toxic effect on the myocardium, reducing the force of contraction (Steel et al., 1967). These two effects can combine to produce a reduction of cardiac output incompatible with survival even in the absence of asystole or ventricular fibrillation.

The turning point in this child's recovery was the restoration of sinus rhythm, which must have been beneficial in two respects. Firstly, the return of co-ordinated atrioventricular activity restored the contribution of atrial systole to ventricular function (Kosowsky et al., 1968). Secondly, the return of normal intraventricular conduction in the transmitted beats improved the power of ventricular contraction (Scherlag et al., 1967).

We wish to thank Dr. D. A. Chamberlain for help in the preparation of this paper, and also Dr. M. E. Fielding and Dr. G. W. Hatcher for permission to report this case. In addition we thank the nursing staff of the intensive care unit, without whose care this child would not have survived.

\section{References}

British Medical fournal, 1974, 1, 296.

Goel, K. M. and Shanks, R. A. (1974). British Medical fournal, 1, 261. Kosowsky, B. D., Scherlag, B. J., and Damato, A. N. (1968). American osowsky, B. D., Scherlag, B. Fournal of Cardiology, 21, 518.
Scherlag, B. J., Kosowsky, B. D., and Damato, A. N. (1967). Journal of Applied Physiology, 22, 584.

Steel, C. M., O'Duffy, J., and Brown, S. S. (1967). British Medical fournal, 3,663 . 